\title{
Polyphenols Content and Antimicrobial, Antioxidant and Hemolytic Activities of Essential Oils from Four Selected Medicinal Plants Growing in Algeria
}

\author{
Noureddine Halla ${ }^{1,2, *}$, Kebir Boucherit ${ }^{2}$, Bankaddour Zeragui ${ }^{1}$, Abdelkader Djelti ${ }^{1}$, Ziane Belkhedim ${ }^{1}$, \\ Rachida Hassani $^{1}$, Saada Benatallah ${ }^{1}$, Hassiba Djellouli ${ }^{1}$, Oumlkheir Kacimi ${ }^{1}$, Zahia Boucherit-Otmani ${ }^{2}$ \\ ${ }^{1}$ Laboratory of Biotoxicology, Pharmacognosy and Biological recovery of plants, Department of Biology, Faculty of Sciences, \\ University of Saida - Dr. Moulay-Tahar, 20000, Algeria. \\ ${ }^{2}$ Antibiotics Antifungal Laboratory, Physical Chemistry, Synthesis and Biological Activity (LAPSAB), Department of Biology, Faculty of Sciences, \\ University of Tlemcen, BP 119, Tlemcen, 13000, Algeria. \\ Corresponding author* \\ halla.nour@yahoo.fr; noureddine.halla@univ-saida.dz
}

Manuscript received: 12 July, 2020. Revision accepted: 10 November, 2020. Published: 13 November, 2020.

\begin{abstract}
The Saharan and steppe spontaneous plants are very characteristic because of their particular adaptation to the desert and extreme environment. Some species have pharmacological properties that give them a medicinal interest. The aim of the present work was to determine the polyphenol contents of essential oils obtained from four endemic plants growing in Algeria (Pituranthos scoparius, Myrtus nivellei, Rosmarinus officinalis and Mentha piperita), and study its biological activity, including antimicrobial, antioxidant, and hemolytic. The antimicrobial activity was evaluated by the microdilution method against twelve strains. The antioxidant activity was carried out by two methods (DPPH radical scavenging and reducing power). However, the hemolytic effect has been evaluated against the red blood cells. $P$. scoparius and $M$. piperita showed yields of essential oils higher than $1 \%$. All the strains showed sensitivity against the essential oils tested with the exception of the $C$. albicans treated by $R$. officinalis essential oils. The most sensitive strain was $C$. albicans treated by $P$. scoparius essential oils by MIC of $0.0781 \mathrm{mg} / \mathrm{mL}$, it was the same plant that shows the highest polyphenol content $(14.78 \pm$ $0.72 \mathrm{~g} \mathrm{GAE} / \mathrm{g}$ DS). The antioxidant activity by the DPPH method was greater for all essential oils tested by $\mathrm{IC}_{50}$ ranging from $0.69 \pm 0.07$ ( $R$. officinalis) to $30.67 \pm 2.12 \mathrm{mg} / \mathrm{mL}$ (M. nivellei). The $R$. officinalis essential oils reported more antioxidant power than the positive control (ascorbic acid). In reducing iron, it was the $R$. officinalis essential oils which were found to be the most active with an $\mathrm{EC}_{50}$ concentration of $9.67 \pm 1.36 \mathrm{mg} / \mathrm{mL}$. After $120 \mathrm{~min}$ incubation, minimal haemolysis $(10 \%)$ was obtained with essential oils of $R$. officinalis at a concentration of $0.39 \mathrm{mg} / \mathrm{mL}$. We conclude that $P$. scoparius essential oils showed the high content of polyphenols and $R$. officinalis essential oils reported more antioxidant power than the positive control (ascorbic acid).
\end{abstract}

Keywords: Polyphenols; Antimicrobial; Antioxidant; Essential oils; Hemolytic; Mentha piperita; Myrtus nivellei; Pituranthos scoparius; Rosmarinus officinalis; Sahara.

\section{INTRODUCTION}

The total Algerian flora has about 16,000 plant species, of which more than 1,000 species with medicinal properties and 700 species are endemics. Algeria is the source of significant taxonomic, ecosystem and landscape diversity (APS, 2019). The spontaneous plants in Sahara area have many uses, traditionally practiced by the local population, in terms of pharmaceuticals, food and domestic use. These plants have the ability to synthesize many compounds called secondary metabolites and thus constitute an immense reservoir of compounds of great chemical diversity, possessing a wide range of biological activities (Seca and Pinto, 2019). This is the case, for example, of plant essential oils which are widely used in therapeutics. In recent years, studies of biological activities of medicinal plants have increased remarkably because of their potential to be used as sources of drugs, food additives or active ingredients in cosmetics (Haddouchi et al., 2016). In this context, the aim of the present work was to determine the polyphenol contents of essential oils obtained from four endemic plants growing in Algeria (Pituranthos scoparius, Myrtus nivellei, Rosmarinus officinalis and Mentha piperita), and study its biological activity, including antimicrobial, antioxidant, and hemolytic. Pituranthos scoparius and Myrtus nivellei are from Tassili n'Ajjer (Sahara), Rosmarinus officinalis and Mentha piperita are from El Bayadh and Tiffrit, respectively (steppe area). 


\section{MATERIAL AND METHODS}

\section{Plant Material and Essential Oil Extraction}

For the four plants studied, the flowering aerial parts were used. The plant material was identified by Dr. Tayeb Si Tayeb (Laboratory of Biotoxicology, Pharmacognosy and Biological recovery of plants, University of Moulay-Tahar, Saida, Algeria). A voucher specimen was deposited at the Herbarium of the Laboratory under the following code numbers LBPBPTS03-13. Pituranthos scoparius and Myrtus nivellei were collected in October 2018 and April 2018, respectively, from Tassili n'Ajjer in south-east Algeria $\left(25^{\circ} 30^{\prime} 0^{\prime \prime} \mathrm{N}\right.$ and $\left.9^{\circ} 0^{\prime} 0^{\prime \prime} \mathrm{E}\right)$. Rosmarinus officinalis was collected in October 2018 from El Bayadh (3340'49" N and $\left.1^{\circ} 01^{\prime} 13^{\prime \prime} \mathrm{E}\right)$. Mentha piperita was collected in July 2018 from Tiffrit (Wilaya of Saida) (34 54'0.01" N and $0^{\circ} 24^{\prime} 0 " \mathrm{E}$ ).

Using a Clevenger-type apparatus, $400 \mathrm{~g}$ of dried plant materials were subjected to hydro-distillation in $4,000 \mathrm{~mL}$ of distilled water for $4 \mathrm{~h}$. The obtained oil was dried over anhydrous sodium sulfate and then stored in sealed glass vials at $4{ }^{\circ} \mathrm{C}$ prior to analysis (El Asbahani et al., 2015).

\section{Total Polyphenols Content}

The polyphenols are assayed according to the method described by Dewanto et al. (2002). A $100 \mu \mathrm{L}$ quantity of each essential oil was mixed with $2 \mathrm{~mL}$ of a freshly prepared sodium carbonate solution (2\%). After five minutes, $100 \mu \mathrm{L}$ of the Folin-Ciocalteu reagent $(1 \mathrm{~N})$ was added to the mixture, the whole was left for 30 minutes at room temperature and the reading is performed against a blank using a spectrophotometer at $750 \mathrm{~nm}$. A standard range based on gallic acid is also prepared. The total polyphenol contents of the essential oils are then expressed in milligrams gallic acid equivalent per gram of the dried sample (mg EAG/g DS) (Halla et al., 2019a).

\section{Antibacterial and Antifungal Activity}

The antimicrobial activity of the essential oils was evaluated using different strains; Gram-positive bacteria: Staphylococcus aureus ATCC 25923 and Bacillus cereus ATCC 11778; Gram-negative bacteria: Escherichia coli ATCC 25933, Pseudomonas aeruginosa ATCC 27853, Pasteurella multocida ATCC 43137, Salmonella typhimurium ATCC 13311, Salmonella enterica ATCC 13312, Campylobacter fetus ATCC 27374, Klebsiella pneumonia ATCC 700603 and Enterobacter cloacae ATCC 13047; and fungal microorganisms (yeasts): Candida albicans ATCC 10231 and Candida albicans IP 444. Bacteria were cultured at $37{ }^{\circ} \mathrm{C}$ for $18 \mathrm{~h}$ under aerobic conditions in Nutrient agar medium (Fluka, USA). Before experimental use, the cultures from different solid mediums were cultivated in liquid media, incubated, and used as the inoculum for each experiment. Mueller-
Hinton broth (bacteria) and RPMI-1640 (yeast) were used for antimicrobial tests (CLSI, 2008; CLSI, 2012).

The minimum inhibitory concentration (MIC) was determined based on the methods approved by the National Committee for Clinical Laboratory Standards (CLSI, 2008; CLSI, 2012), with slight modifications (Halla et al., 2019b). The Microtiter plates were inoculated within different concentration of essential oils and then incubated at $37{ }^{\circ} \mathrm{C}$ for Bacteria or $35{ }^{\circ} \mathrm{C}$ for $C$. albicans in a moist dark chamber. The MIC of each sample was recorded after 16-20 h of incubation for Bacteria and $24 \mathrm{~h}$ for $C$. albicans. End points were defined as the lowest concentration of antibacterial agent resulting in total inhibition of visual growth compared to the growth in the control wells containing no essential oil. The minimum bactericidal concentration (MBC) and fungicidal concentration (MFC) were also determined. After determining the MIC, $50 \mu \mathrm{L}$ (Bacteria) or $20 \mu \mathrm{L}$ (C. albicans) samples were withdrawn from each well of the microtiter tray with a 96-pin replicator (Boekel Scientific, Feasterville, PA, USA) and plated onto nutrient agar (Bacteria) or Sabouraud dextrose agar plates (C. albicans). Inoculated plates were incubated at $37^{\circ} \mathrm{C}$ for $24 \mathrm{~h}$ (Bacteria) or $35^{\circ} \mathrm{C}$ for $48 \mathrm{~h}$ (C. albicans) before determining the MBC (or MFC), which was defined as the lowest concentration of essential oil that resulted in total inhibition of visible growth (EspinelIngroff and Cantón, 2007; Qaiyumi, 2007).

\section{Antioxidant Activity}

\section{- DPPH Radical Scavenging Activity}

The experimental protocol followed that of Prieto et al. (1999). Fifty microliters of essential oil at different concentrations were added to $1950 \mu \mathrm{L}$ of a methanolic solution of DPPH at $6.34 \times 10^{-5} \mathrm{M}$. A blank (negative) control was prepared by mixing $50 \mu \mathrm{L}$ of methanol with $1950 \mu \mathrm{L}$ of the methanolic solution of DPPH. After incubation in the dark for $30 \mathrm{~min}$ at room temperature, the reduction of DPPH was evidenced by the color change of the solution from violet to yellow. The absorbance of this solution was then determined at 515 nm using a spectrophotometer. The positive control used is Ascorbic acid.

The results were expressed as percent inhibition (PI), and this was calculated based on the reduction of the color intensity of the solution using the formula:

$$
\mathrm{PI}=\left(\mathrm{OD}_{\text {control }}-\mathrm{OD}_{\text {essential oils }} / \mathrm{OD}_{\text {control }}\right) \times 100
$$

Where $\mathrm{OD}_{\text {control }}$ is the absorbance of the negative control and $\mathrm{OD}_{\text {essential oils }}$ is the absorbance with the essential oils. $\mathrm{IC}_{50}$ value is the concentration corresponds to $50 \%$ inhibition (Zeragui et al., 2019).

\section{- Reducing Power Assays}

The reducing power is determined according to the method described by Oyaizu (1986). A volume of $1 \mathrm{~mL}$ 
of each essential oil at different concentrations was mixed with $2.5 \mathrm{~mL}$ of $0.2 \mathrm{M}$ phosphate buffer ( $\mathrm{pH} 6.6$ ) and $2.5 \mathrm{~mL}$ of $1 \%$ potassium ferricyanide solution. The mixture obtained was incubated for $20 \mathrm{~min}$ at $50^{\circ} \mathrm{C}$. After this period, $2.5 \mathrm{~mL}$ of $10 \%$ trichloroacetic acid was added to stop the reaction. The resulting mixture was centrifuged at $650 \times \mathrm{g}$ for $10 \mathrm{~min}$ at room temperature, and $2.5 \mathrm{~mL}$ of the resulting supernatant was added to $2.5 \mathrm{~mL}$ of distilled water and $0.5 \mathrm{~mL}$ of 0.1 $\%(\mathrm{w} / \mathrm{v})$ iron chloride. The absorbance of this solution at $700 \mathrm{~nm}$ was compared to that of a blank solution and the activity of the essential oil was compared with that of the positive control, i.e., butylhydroxyanisole (BHA). The results allow calculation for effective concentration $\left(\mathrm{EC}_{50}\right)$, concentration of the corresponding essential oils with an absorbance equal to 0.5 (Halla et al., 2019a).

\section{Hemolytic Assay}

Red blood cells were isolated and suspended in PBS $(100 \mathrm{mM}$ at $\mathrm{pH} 7.4)$ at a rate of 4000 cells $/ \mathrm{mL}$. The erythrocyte suspension was incubated at $37{ }^{\circ} \mathrm{C}$ under continuous agitation for $120 \mathrm{~min}$, from the addition of essential oil solution with DMSO (Dimethyl sulfoxide) at different final concentrations. Samples of $50 \mu \mathrm{L}$ from the reaction solution were made at regular intervals to which we added $2 \mathrm{ml}$ of cold washing solution $(150 \mathrm{mM}$ of $\mathrm{NaCl}, 2 \mathrm{mM}$ of $\mathrm{MgCl}_{2}$ ). After centrifugation at 4000 rpm for $5 \mathrm{~min}$, the absorption of the resulting supernatant was determined at $548 \mathrm{~nm}$ by photometric monitoring against a blank sample. Control samples of $0 \%$ lysis (in buffer) and 100\% lysis (in double-distilled water) were employed in all experiments (Bolard, 1986; Halla et al., 2013; Silva et al., 2017).

\section{Statistical Analysis}

The yields obtained, polyphenols content and antioxidant activity tests were carried out in triplicate and the results are expressed in mean values \pm standard deviation. All analyzes were performed in the Microsoft Excel for Windows program, 2007.

\section{RESULTS AND DISCUSSION}

\section{Extraction Yield}

In this study, we were interested in the study of different essential oils obtained by hydrodistillation of the aerial parts of four Algerian plants. The two studied plants, Pituranthos scoparius and Myrtus nivellei, were collected in the Tassili n'Ajjer region in the wilaya of Tamanrasset (south of Algeria). The Tassili National Park has been listed as a UNESCO World Heritage Site since 1982 and has been classified as a man and biosphere reserve since 1986 . It is characterized by a contrasted landscape of rugged mountainous terrain and desert plateau of black rocks which form the Reg or white sands. The central barrier of $1500-2000 \mathrm{~m}$ in altitude extends over $800 \mathrm{~km}$ and covers $80,000 \mathrm{~km}^{2}$ (Hammiche and Maiza, 2006). The two plants Rosmarinus officinalis and Mentha piperita were harvested in the steppe area (Saida and El Bayadh). In Algeria, the steppe constitutes a vast region which extends between the Tellian Atlas in the North and the Saharan Atlas in the South, extending over a land area of around 20 million hectares. The altitude ranges from 400 to 1,200 meters. The steppe is characterized by a strong climatic constraint (insufficient rainfall with an isohyet varying from 100 to $400 \mathrm{~mm}$, strong and sometimes hot winds, etc.) and edaphic (vulnerable soils, thin and poor in organic matter) (Khaldi, 2014).

The various yields obtained are reported in Table 1. $P$. scoparius and $M$. piperita showed yields higher than $1 \%$, however, the yields of $M$. nivellei and $R$. officinalis were of the order of 0.81 and $0.76 \%$, respectively.

Table 1. Yields and total polyphenols content of essential oils of Pituranthos scoparius, Myrtus nivellei, Rosmarinus officinalis and Mentha piperita.

\begin{tabular}{lll}
\hline & Yields (\%) & Total polyphenols content mg GAE/g DS* \\
\hline Pituranthos scoparius & $1.081 \pm 0.061$ & $14.78 \pm 0.72$ \\
Myrtus nivellei & $0.81 \pm 0.02$ & $0.611 \pm 0.056$ \\
Rosmarinus officinalis & $0.76 \pm 0.42$ & $0.279 \pm 0.087$ \\
Mentha piperita & $1.10 \pm 0.13$ & $0.104 \pm 0.012$ \\
\hline
\end{tabular}

Pituranthos scoparius essential oil had a specific odour (odour of fennel) and was colorless. The yield of essential oils of Pituranthos scoparius was $1.081 \pm$ $0.061 \%$, which is in agreement with that obtained by Lograda et al. (2013) from the same plant collected in Mechouneche (Biskra). However, the same authors found yields of $0.47 \%, 0.85 \%$ and $2.29 \%$ in different regions (T'Kout (Batna), Boussâada (M'sila), and ElKantra (Biskra), respectively) when the plant was harvested in October. Gourine et al. (2011) obtained yields ranging from 0.6 up to $2.8 \%$. Ksouri et al. (2017) studied the essential oil of Pituranthos scoparius harvested in the wilaya of Tamanrasset, they found a yield of $0.4 \%$ which is different than that obtained in our study. Our result was not correlated with that obtained by Vérité et al. (2004) (0.77\% from the seeds and $0.50 \%$ from the stems of the plant harvested in April), Kalla et al. (2010) $(0.25 \%$ and $0.3 \%$ of the aerial part of the plant 
harvested in February and April, respectively), Abderrazak et al. (2013) (0.25\% of the aerial part of the plant harvested in October) and Chikhoune et al. (2017) $(0.502 \%$ of the aerial part of the plant harvested in April).

The essential oil of $M$. nivellei was pleasant with a light yellow colour. The yield was $0.81 \pm 0.02 \%$. This result is supported by that obtained by Bouzabata et al. (2013) from the Hoggar zone, which was not the case with that harvested from Tassili n'Ajjer where these authors found yields ranging from 0.5 to $0.9 \%$. Boukhalfa (2017) obtained that the yield was $1.6 \%$ of this plant harvested in the months of September and October in the Tagmart region in Tamanrasset. Unlike the abundant literature relating to the essential oil of Myrtus comunis in Algeria, studies on the essential oils of $M$. nivellei are counted on the fingers. Pereira et al. (2009) suggested that the highest yields of the essential oils of Myrtus comunis were obtained for the leaves in October. As well as, the samples taken in May and October produced very little oil. Altogether, September seems to be the month with the best yields for the different parts of the plant.

The yield of essential oils of Rosmarinus officinalis $(0.76 \pm 0.42 \%)$ is lower than those found by Jordán et al. (2013) of the various essential oils of Rosmarinus officinalis harvested in thermo Mediterranean, upper meso- and supra-Mediterranean areas in Spain, which are of the order of $1.74 \pm 0.38,2.44 \pm 1.26$ and $2.58 \pm$ $0.75 \%$, respectively. Zaouali et al. (2010) reported that the yields of essential oils of this plant harvested in Tunisia from three different zones (sub-humid, upper semi-arid and upper arid zone) are between 1.17 and 2.7\%. A study by Djeddi et al. (2007) recorded a yield of $0.82 \%$. This result seems very close to our result, may be due to the same origin of the two plants (Algeria).

The essential oil of Mentha piperita was pale yellow with a strong aromatic odour. The essential oil yield of Mentha piperita was $1.10 \pm 0.13 \%$. Work carried out on the same species in Algeria (Ghardaiia) revealed a yield close $(1.325 \%)$ to the value obtained by our study on the essential oil of $M$. piperita (Laghouiter et al., 2015). Another study in Morocco showed a yield around 1.02\% (Derwich et al., 2010). On the other hand, yield values for essential oil of $M$. piperita have been recorded by several authors from different countries, and which are higher or lower than that obtained by our study. Singh et al. (2015) revealed a yield of about $0.64 \%$ from the leaves of $M$. piperita harvested in Libya. A yield of $2.29 \%$ was recorded by Gavahian et al. (2015) of the aerial part of the same plant harvested in Iran. Laghouiter et al. (2015) reported that the extraction yield was very low during the cold period (autumn and winter), however the best yields were obtained in Summer and Spring during the flowering period of the plant. Rohloff et al. (2005) studied the effect of the harvest time and the drying method on the essential oil yield of Mentha piperita, and they concluded that the harvest of this plant should be carried out at full flowering to obtain the best yield.

This difference may be due to the geographical origin of the plant as well as to the harvest period. According to some authors, the harvest season can affect the variation in the yield of essential oils (Boukhalfa, 2017). Others explain this difference by the harvest period and the drying method (Rohloff et al., 2005). Other factors are likely to influence the difference in yield. Precipitation can particularly affect the yield of essential oils (Sangwanet al., 2001).

Plant ontogenesis can be one of the most important factors that influence the accumulation of essential oils in plants. Since many transformations and changes occur inside cells due to physiological processes, the harvest season and the organ used are often considered to be critical parameters that can affect the chemical compositions of essential oils (Lee and Ding, 2016).

\section{Total Polyphenols Content}

The total phenol content is determined from the equation of the linear regression of the gallic Acid calibration curve: $y=0.005 x+0.185\left(R^{2}=0.996\right)$ and the results are expressed in $\mathrm{mg}$ gallic acid equivalents per $\mathrm{g}$ of dried sample (mg GAE/g DS). Table 1 summarizes the results for essential oils of four species tested. From the results obtained, we observed a high content of polyphenols in the $P$. scoparius essential oils (14.78 \pm $0.72 \mathrm{mg}$ GAE/g DS), however, the essential oils of $M$. nivellei, $R$. officinalis and $M$. piperita contain $0.611 \pm$ $0.056,0.279 \pm 0.087$ and $0.104 \pm 0.012 \mathrm{mg} \mathrm{GAE} / \mathrm{g} \mathrm{DS}$, respectively.

The total phenol contents are variable between the four plants. The total phenol content found by Wojdylo et al. (2007), in essential oils of Rosmarinus officinalis $(1.71 \pm 0.02 \mathrm{mg} \mathrm{GAE} / \mathrm{g} \mathrm{DS})$ is greater than our value $(0.279 \pm 0.087 \mathrm{mg} \mathrm{GAE} / \mathrm{g}$ DS $)$.

For the essential oils of $M$. piperita, the total phenol content is lower than that of the same species previously studied by Zheng and Wang (2001); it is about 2.26 $\pm 0.16 \mathrm{mg}$ of GAE/g of fresh weight.

Studies on the extract of $M$. nivellei leaves indicated that the hydromethanolic, ethyl acetate, butanolic and aqueous fraction had the highest values in phenolic content $(222.98 \pm 4.70,308.4 \pm 7.40,414.96 \pm 2.40$ and $128.03 \pm 1.87 \mathrm{mg} \mathrm{GAE} / \mathrm{g}$ DS, respectively) (Ramdane et al., 2017). In another study on the aqueous extract of the leaves of $M$. nivellei, the level of total polyphenols was estimated around $242.68 \pm 9.79 \mathrm{mg}$ GAE/g DS (Rached et al., 2010).

Lograda et al. (2013) reported the variation in the composition of the essential oils of Pituranthos scoparius in Algeria and they recorded that these oils are very rich in alcoholic compounds such as terpinene-4-ol, p-cymèn-8-ol, $\quad \beta$-eudesmol, $\quad$ Methyl-eugenol, spathulenol, linalool, $\gamma$ cadinol and t-muurolol. 
The value of the polyphenol content of Mentha piperita is not in agreement with those obtained by Sharafi et al. (2010), from the plant harvested in Iran, where the polyphenol level was $89.43 \pm 0.58,40.43 \pm$ $0.58,15.10 \pm 1$ and $9.43 \pm 0.58 \mu \mathrm{g} \mathrm{GAE} / \mathrm{mg}$ sample for oil concentrations of the order of 10, 5, 2.5 and 0.2 $\mu \mathrm{g} / \mathrm{mL}$. Atanassova et al. (2011) showed that the methanolic extract of Mentha piperita contains a polyphenol level of $0.4525 \mathrm{mg}$ GAE/g DS where this plant was harvested in Bulgaria. The level of total polyphenols was estimated to be around $71.8 \pm 5.1$ and $55.1 \pm 3.6 \mathrm{mg} \mathrm{GAE} / \mathrm{g}$ DS of the methanol/chloroform extract and the aqueous extract from the leaves and stems of Mentha piperita harvested in Pakistan (Akhtar et al., 2018). Riachi and De Maria (2015) concluded that the composition of Mentha piperita oil is very sensitive to environmental variations where the maturity of the leaves plays an important role in the composition of the essential oil. Thus, mint plants harvested at the flowering stage usually have a higher concentration of menthol (phenol) than plants in the bud-forming process, which contain a high amount of menthone. Another factor, the exposure of the plant Mentha piperita to UV-A radiation in addition to white light, during the night, increased the phenol content (Maffei et al., 1999). In short, longer days, colder nights, older leaves, plants harvested at the flowering stage, and adequate hydration of plants should provide good quality peppermint essential oil (Riachi and De Maria, 2015).

By comparison with previous studies, it seems that the extraction of phenolic compounds is governed by several factors which directly influence the levels of these molecules among these factors; increasing the extraction temperature, contact time of the plant material with water, and decreasing the particle size to increase the diffusion coefficient of the water.

\section{Antibacterial and Antifungal Activity}

The obtained results of the antibacterial and antifungal activity (Minimum inhibitory concentration 'MIC' and minimum bactericidal (fungicidal) concentration ' $\mathrm{MBC}$ ' -'MFC') of the essential oils of the four plants are presented in Table 2. All the strains showed sensitivity against the essential oils tested with the exception of the $C$. albicans against $R$. officinalis essential oils. All essential oils tested are less active than the positive control (Gentamicin or Ketoconazole) with the exception of Rosmarinus officinalis essential oils against Salmonella typhimurium (MIC and $\mathrm{MBC}=0.625$ $\mathrm{mg} / \mathrm{mL}$ ), Salmonella enterica (MIC $=0.0825 \mathrm{mg} / \mathrm{mL}$ and $\mathrm{MBC}=0.312 \mathrm{mg} / \mathrm{mL}$ ) and Klebsiella pneumonia $(\mathrm{MIC}=0.3125 \mathrm{mg} / \mathrm{mL}$ and $\mathrm{MBC}=1.25 \mathrm{mg} / \mathrm{mL}$ ), as well as essential oils of Mentha piperita against Staphylococcus aureus $(\mathrm{MIC}=0.078 \mathrm{mg} / \mathrm{mL}$ ). The strains treated by $P$. scoparius essential oils showed that the most sensitive strain was $C$. albicans ATCC 10231 by MIC of $0.0781 \mathrm{mg} / \mathrm{mL}$. On the other hand, all bacteria tested against $P$. scoparius in this study revealed MICs of 5, 10 or higher than $10 \mathrm{mg} / \mathrm{mL}$. E. coli was the most sensitive bacteria tested by $M$. nivellei essential oils with MIC around $2.5 \mathrm{mg} / \mathrm{mL}$, while, the fungal strains showed good MIC $(0.312 \mathrm{mg} / \mathrm{mL})$ by comparing with those obtained against bacteria.

Table 2. Minimum inhibitory concentrations and minimum bactericidal (fungicidal) concentrations $(\mathrm{mg} / \mathrm{mL}$ ) of essential oils (Pituranthos scoparius, Myrtus nivellei, Rosmarinus officinalis and Mentha piperita) and controls.

\begin{tabular}{|c|c|c|c|c|c|c|c|c|c|c|}
\hline \multirow{2}{*}{ Test organisms } & \multicolumn{2}{|c|}{$\begin{array}{c}\text { Pituranthos } \\
\text { scoparius }\end{array}$} & \multicolumn{2}{|c|}{ Myrtus nivellei } & \multicolumn{2}{|c|}{$\begin{array}{l}\text { Rosmarinus } \\
\text { officinalis } \\
\end{array}$} & \multicolumn{2}{|c|}{ Mentha piperita } & \multicolumn{2}{|c|}{ Control $^{\mathrm{d}}$} \\
\hline & $\mathrm{MIC}^{\mathbf{a}}$ & $\begin{array}{l}\mathrm{MBC}^{\mathrm{b}} \\
\left(\mathrm{MFC}^{\mathrm{c}}\right)\end{array}$ & MIC & $\begin{array}{l}\text { MBC } \\
(\mathrm{MFC})\end{array}$ & MIC & $\begin{array}{l}\text { MBC } \\
\text { (MFC) }\end{array}$ & MIC & $\begin{array}{l}\text { MBC } \\
\text { (MFC) }\end{array}$ & MIC & MBC \\
\hline Bacillus cereus ATCC 11778 & 10 & 10 & 5 & 5 & 2.5 & 10 & 5 & 5 & 0.156 & 0.156 \\
\hline Escherichia coli ATCC 25933 & 10 & 10 & 2.5 & 2.5 & 1.25 & 5 & 0.312 & 0.625 & 0.312 & 0.312 \\
\hline Pseudomonas aeruginosa ATCC 27853 & 10 & 10 & 5 & 5 & 2.5 & 5 & 5 & 5 & 0.625 & 1.25 \\
\hline Salmonella typhimurium ATCC 13311 & $>10$ & $>10$ & 10 & 10 & 0.625 & 0.625 & 1.25 & 2.5 & 0.625 & 0.625 \\
\hline Salmonella enterica ATCC 13312 & 5 & 5 & 10 & 10 & 0.0825 & 0.312 & 10 & 10 & 0.625 & 0.625 \\
\hline Campylobacter fetus ATCC 27374 & $>10$ & $>10$ & 10 & 10 & 5 & 10 & 5 & 5 & 0.019 & 0.039 \\
\hline Klebsiella pneumonia ATCC 700603 & 10 & 10 & 10 & 10 & 0.3125 & 1.25 & 2.5 & 5 & 5 & 10 \\
\hline Enterobacter cloacae ATCC 13047 & $>10$ & $>10$ & 5 & 5 & 5 & 10 & 5 & 5 & 2.5 & 5 \\
\hline Candida albicans ATCC 10231 & 0.0781 & 0.0781 & 0.312 & 0.312 & / & / & 0.625 & 2.5 & 0.019 & 0.019 \\
\hline Candida albicans IP 444 & 0.039 & 0.039 & 0.312 & 1.25 & / & I & 5 & 5 & 0.019 & 0.019 \\
\hline
\end{tabular}

Concerning $R$. officinalis, S. enterica recorded the lowest MIC compared to the other tested bacteria $(0.0825 \mathrm{mg} / \mathrm{mL})$. By comparison, Gram negative bacteria were more sensitive than Gram positive against R. Officinalis essential oils. Indeed, the registered MICs of M. piperita essential oils for B. cereus, $P$. aeruginosa, 
S. enterica, C. fetus, E. cloacae and C. albicans IP 444 (from 5 to $10 \mathrm{mg} / \mathrm{mL}$ ) were higher than those obtained for S.aureus, E.coli, P. multocida, S. typhimurium, K. pneumonia and C. albicans ATCC 10231 (from 0.078 to $2.5 \mathrm{mg} / \mathrm{mL}$ ).

The MICs for Pituranthos scorparius essential oil were similar to those reported by Boutaghane et al. (2004) for Enterobacter, Klebsiella pneumoniae and Salmonella thiphymurium where they found MICs of the order of 256, 16 and $128 \mathrm{mg} / \mathrm{mL}$, respectively. On the other hand, the MIC results obtained by these authors against Escherichia coli (256 mg/mL), Pseudomonas aeruginosa $(1 \mathrm{mg} / \mathrm{mL})$ and Staphylococcus aureus $(256$ $\mathrm{mg} / \mathrm{mL}$ ) are not in agreement with our results. Ksouri et al. (2017) found that no antibacterial activity of Pituranthos scorparius essential oil has been revealed against Escherichia coli and Klebsiella pneumoniae. However, the MICs obtained for Staphylococcus aureus and Candida albicans were of the order of 1 and 0.5 $\mathrm{mg} / \mathrm{mL}$. The MIC obtained by Ksouri et al. (2017) against Pseudomonas aeruginosa (greater than or equal to $2 \mathrm{mg} / \mathrm{mL}$ ) is correlated with that of our result.

Bouzabata et al. (2013) studied the antifungal activity of the essential oil of Myrtus nivellei (same species in Algeria), they showed MICs and MFCs between 1.25 and $2.5 \mu \mathrm{L} / \mathrm{mL}$ against Candida albicans ATCC 10231. These can be correlated with the CMF obtained against Candida albicans IP 444 (1.25 $\mathrm{mg} / \mathrm{mL}$ ).

A work by Kabouche et al. (2005) on essential oils of Rosmarinus officinalis grown in Algeria showed MICs greater than $0.128 \mathrm{mg} / \mathrm{ml}$ against both strains $E$. coli and $S$. aureus. The results of the CMI are in agreement with those obtained by Celiktas et al. (2007) from Turkey (Izmir, Çanakkale) of the essential oils of the plant harvested in September against the Staphylococcus aureus $(10 \mathrm{mg} / \mathrm{mL})$. However, a Tunisian study reported that essential oils of this species revealed MICs between 1.25-2.5 $\mu \mathrm{L} / \mathrm{mL}$ against $E$. coli and between 1.25-2.5 $\mu \mathrm{L} / \mathrm{mL}$ against Bacillus cereus (Zaouali et al., 2010). It is comparable to our results. According to Jordán et al. (2013), these essential oils have an MIC of $2-5 \mu \mathrm{L} / \mathrm{mL}$ against $E$. coli.

İşcan et al. (2002) tested the essential oil of $M$. piperita from different origins (Turkey and India), they reported MICs between 1.25 and $2.5 \mathrm{mg} / \mathrm{mL}$ against Escherichia coli, between 0.625 and $2.5 \mathrm{mg} / \mathrm{mL}$ against Staphylococcus aureus, between 1.25 and $2.5 \mathrm{mg} / \mathrm{mL}$ against Salmonella typhimurium, of $2.5 \mathrm{mg} / \mathrm{mL}$ against Klebsiella pneumoniae, of $1.25 \mathrm{mg} / \mathrm{mL}$ against Bacillus cereus and between 0.312 and $0.625 \mathrm{mg} / \mathrm{mL}$ against Candida albicans. These results are correlated with our results, with the exception of those obtained for Escherichia coli and Bacillus cereus. The MIC values for essential oil of $M$. piperita against different bacterial strains, reported by Mahboubi and Kazempour (2014), range from 0.125 to a value greater than $64 \mu \mathrm{L} / \mathrm{mL}$. The
MICs are of the order of 1, 0.25, 1, 2, 16, 0.25 and 0.125 $\mu \mathrm{L} / \mathrm{mL}$ against $S$. aureus, B. cereus, E. coli, $S$. typhimurium, $P$. aeruginosa, $K$. pneumioniae and $C$. albicans, respectively. However, the MBCs are of the order of 2,> 64, 1, 2, 160.5 and $0.125 \mu \mathrm{L} / \mathrm{mL}$ against $S$. aureus, B. cereus, E. coli, $S$. typhimurium, $P$. aeruginosa, $K$. pneumioniae and $C$. albicans, respectively. Mohammadi et al. (2016) revealed percentages of $0.16 \%, 0.8 \%$ and $2 \%$ of $\mathrm{MIC}_{50}, \mathrm{MIC}_{90}$ and $\mathrm{MBC}$, respectively, of the essential oil of $M$. piperita against $E$. coli. Compared with our result, it seems that the oil tested has a strong activity to that tested by Mohammadi and al. Tyagi and Malik (2011) recorded MIC and MBC (or MFC) of 1.13 to 2.25 $\mathrm{mg} / \mathrm{mL}$ (MIC) and 2.25-9 $\mathrm{mg} / \mathrm{mL}$ (MBC) for bacterial strains and $1.13 \mathrm{mg} / \mathrm{mL}$ (MIC) and $2.25 \mathrm{mg} / \mathrm{mL}$ (MFC) for yeasts. According to the study by Saharkhiz et al. (2012), the essential oils of $M$. piperita have an antifungal activity with an MIC of $1.5 \mu \mathrm{L} / \mathrm{mL}$ against $C$. albican strain. According to the study by Saharkhiz et al. (2012), the essential oils of $M$. piperita have an antifungal activity with a MIC of $1.5 \mu \mathrm{L} / \mathrm{mL}$ against $C$. albicans. Samber et al. (2015) found that M. piperita essential oil is a bioactive fungicidal compound that has a strong effect on PM-ATPase (PM: Plasma Membrane) in Candida species. They suggested these essential oils enter the cell membrane and target the pathway for ergosterol biosynthesis, thereby compromising its biosynthesis. Simultaneously, they react with the membrane itself with their reactive hydroxyl moiety, and the extensive lesion on the membrane is a combined effect of the two events.

\section{Antioxidant Activity}

The evaluation of the antioxidant activity of the essential oils of the four plants was carried out by two conventional methods in order to test these essential oils by various reaction mechanisms involved in these antioxidant tests.

The DPPH radical is one of the most widely used substrates for the rapid and direct evaluation of antioxidant activity due to its stability in radical form and the simplicity of this analysis. The antioxidant power of the essential oils has been compared to that of the positive control used (Ascorbic acid). The values of the concentrations corresponding to the inhibition of $50 \%$ of the free radical DPPH $\left(\mathrm{IC}_{50}\right)$ are summarized in Table 3.

From the results obtained, we observed that the essential oils of the four plants showed an antioxidant activity by scavenging of the free radical DPPH. By comparing the antioxidant power of ascorbic acid (positive control) with that of the essential oils of $P$. scoparius, $M$. nivellei and $M$. piperita, we note that these essential oils were less active and showed a weak antioxidant activity relative to ascorbic acid. However, the $R$. officinalis essential oils $\left(\mathrm{IC}_{50}=0.69 \pm 0.07\right.$ 
$\mathrm{mg} / \mathrm{mL}$ ) reported more antioxidant power than the ascorbic acid $\left(\mathrm{IC}_{50}=0.81 \pm 0.14 \mathrm{mg} / \mathrm{mL}\right)$. From the results obtained, the essential oils of $P$. scoparius, $M$. nivellei and $M$. piperita have $\mathrm{IC}_{50}$ values of $3.26 \pm 0.65$, $30.67 \pm 2.12$ and $18.33 \pm 1.84 \mathrm{mg} / \mathrm{mL}$, respectively.

Table 3. $\mathrm{IC}_{50}$ values for reduction of radical DPPH and $\mathrm{EC}_{50}$ of reducing power of essential oils of Pituranthos scoparius, Myrtus nivellei, Rosmarinus officinalis and Mentha piperita $(\mathrm{mg} / \mathrm{mL})$.

\begin{tabular}{lll}
\hline & IC50 DPPH & $\begin{array}{l}\text { EC50 reducing } \\
\text { power }\end{array}$ \\
\hline Ascorbic acid & $0.81 \pm 0.14$ & $/$ \\
\hline BHA & $/$ & $0.42 \pm 0.12$ \\
Pituranthos scoparius & $3.26 \pm 0.65$ & $484.40 \pm 5.14$ \\
Myrtus nivellei & $30.67 \pm 2.12$ & $31.2 \pm 2.59$ \\
Rosmarinus officinalis & $0.69 \pm 0.07$ & $9.67 \pm 1.36$ \\
Mentha piperita & $18.33 \pm 1.84$ & $11.07 \pm 0.07$ \\
\hline
\end{tabular}

The values of the optical densities obtained by reducing power assays allowed to drawing curves for each essential oil. In this test, the increase in absorbance means an increase in the reducing power of the essential oils tested. In order to compare the antioxidant activity of the essential oils tested by this method, we calculated the $\mathrm{EC}_{50}$. The results obtained are illustrated in Table 3. We note that the essential oils of the $P$. scoparius showed a very low reducing power by comparing them with the positive control used (BHA) and the essential oils of the other plants $(484.40 \pm 5.14 \mathrm{mg} / \mathrm{mL})$. The essential oils of $R$. officinalis reported an $\mathrm{EC}_{50}$ of $9.67 \pm$ $1.36 \mathrm{mg} / \mathrm{mL}$, this time their antioxidant activity have not powerful to those of the positive control BHA $(0.42 \pm$ $0.12 \mathrm{mg} / \mathrm{mL}$ ). The $\mathrm{EC}_{50}$ of $M$. nivellei and $M$. piperita essential oils are $31.2 \pm 2.59$ and $11.07 \pm 0.07 \mathrm{mg} / \mathrm{mL}$, respectively.

The essential oils of Pituranthos scoparius have an $\mathrm{IC}_{50}$ value of $3.26 \pm 0.65 \mathrm{mg} / \mathrm{mL}$ which results in a much higher antioxidant power than the value obtained by Ksouri et al. (2017) which is of the order of $11.21 \pm$ $0.26 \mathrm{mg} / \mathrm{mL}$ of the same species.

To our best knowledge, there is no work done on the antioxidant activity of the essential oils of $M$. nivellei. Touaibia and Chaouch (2014) studied some extracts of this plant, they showed that the extracts studied all had a very good reducing activity, especially for the ethanol extract $\left(\mathrm{EC}_{50}\right.$ equal to $\left.0.59 \mathrm{mg} / \mathrm{mL}\right)$ by the $\mathrm{DPPH}$ method and methanol extract by the FRAP test $(66.7 \%)$. Rached et al. (2010) evaluated the antioxidant activity of the fractions obtained from the raw extract of the leaves of $M$. nivellei. They found that the best activity was reported for the ethyl acetate and n-butanol fractions with $\mathrm{IC}_{50}$ values of $3.08 \pm 0.40 \mu \mathrm{g} / \mathrm{mL}$ and $4.40 \pm 0.43$ $\mu \mathrm{g} / \mathrm{mL}$, respectively. In addition, Ramdane et al. (2017) reported $\mathrm{IC}_{50}$ values between $4.97 \mu \mathrm{g} / \mathrm{mL}$ and 16.33 $\mu \mathrm{g} / \mathrm{mL}$, for the different extracts obtained from $M$. nivellei leaves (hyudromethanol, ethyl acetate, butanolic and aqueous).

The antioxidant activity of essential oils of Rosmarinus officinalis is greater compared to that found by Zaouali et al. (2010) and Wojdylo et al. (2007), which revealed a low antioxidant power, by the two DPPH and FRAP methods.

For the essential oils of $M$. piperita, we compared our results with the work carried out by Singh et al. (2015), on the same species of Libya, which showed a higher antioxidant activity by scavenging the DPPH radical, with an $\mathrm{IC}_{50}$ value of $15.2 \pm 0.9 \mu \mathrm{g} / \mathrm{mL}$. According to Sharafi et al. (2010), the M. piperita essential oil has shown a percentage inhibition of DPPH activity of $63.82 \pm 0.05 \%$ at the concentration of 10 $\mu \mathrm{g} / \mathrm{mL}$ where the $\mathrm{IC}_{50}$ was around $3.9 \mu \mathrm{g} / \mathrm{ml}$. Laghouiter et al. (2015) recorded an $\mathrm{EC}_{50}$ of around $208.495 \pm$ $4.247 \mu \mathrm{g} / \mathrm{mL}$ of $M$. piperita essential oil. Gavahian et al. (2015) extracted the essential oil from $M$. piperita by four different methods (hydrodistillation; steam entrainment, hydrodistillation assisted by microwaves and hydrodistillation assisted by ohmic heating). They found that the antioxidant activity was almost similar for the essential oil obtained by these different methods whose $\mathrm{EC}_{50}$ values were between $9.6 \pm 0.7$ and $10.4 \pm$ $0.6 \mu \mathrm{g} / \mathrm{mL}$. Our results, in most cases, are not in agreement with those obtained by previous work. This difference in the results is probably due to the diversity of the chemical composition and according to intrinsic and extrinsic factors, namely the harvest region and the evaluation method used.

\section{Hemolytic Asssay}

The hemolysis test was evaluated because, even if a plant has potent antioxidant power or good antimicrobial activity, its use in traditional medicine and in pharmacological preparations will be impossible in the presence of their hemolytic effect, which is an indicator of cytotoxicity. When the plasma membrane of red blood cells is altered by the action of essential oil, it follows lysis resulting in the release of hemoglobin in the red blood cell, which is why we assayed the extracellular hemoglobin after the addition of different concentrations of essential oils. Final concentrations of essential oils were chosen according to the MIC founded in the first part. Figure 1 shows the effect of essential oils at different concentrations $(0.39,0.781,1.56$ and $3.125 \mathrm{mg} / \mathrm{mL}$ ) on the release of hemoglobin from the red blood cells at $37^{\circ} \mathrm{C}$.

The results obtained show that the percentages of hemolytic effect are directly proportional to the increase in the concentrations of the essential oils of the four tested plants (Fig. 1). After 120 minutes of incubation and for all the concentrations tested, the hemolysis percentages are between 10 and $93 \%$. Therefore, the hemolytic effect of the various essential oils tested, at the concentration of $3.125 \mathrm{mg} / \mathrm{mL}$ after 120 minutes of contact with human erythrocytes, can be classified as 
follows: P. scoparius (93\%) M. piperita $(72.88 \%)>M$. nivellei $(72.75 \%)>R$. officinalis $(43.26 \%)$. After 120 min incubation, minimal haemolysis $(10 \%)$ is obtained with essential oils of $R$. officinalis at a concentration of $0.39 \mathrm{mg} / \mathrm{mL}$, so these essential oils may be slightly hemolytic at this concentration after two hours of incubation. On the other hand, the other essential oils have an important hemolytic effect against isolated erythrocytes, with a hemolysis rate that exceeds $41 \%$ at a concentration of $0.39 \mathrm{mg} / \mathrm{ml}$.
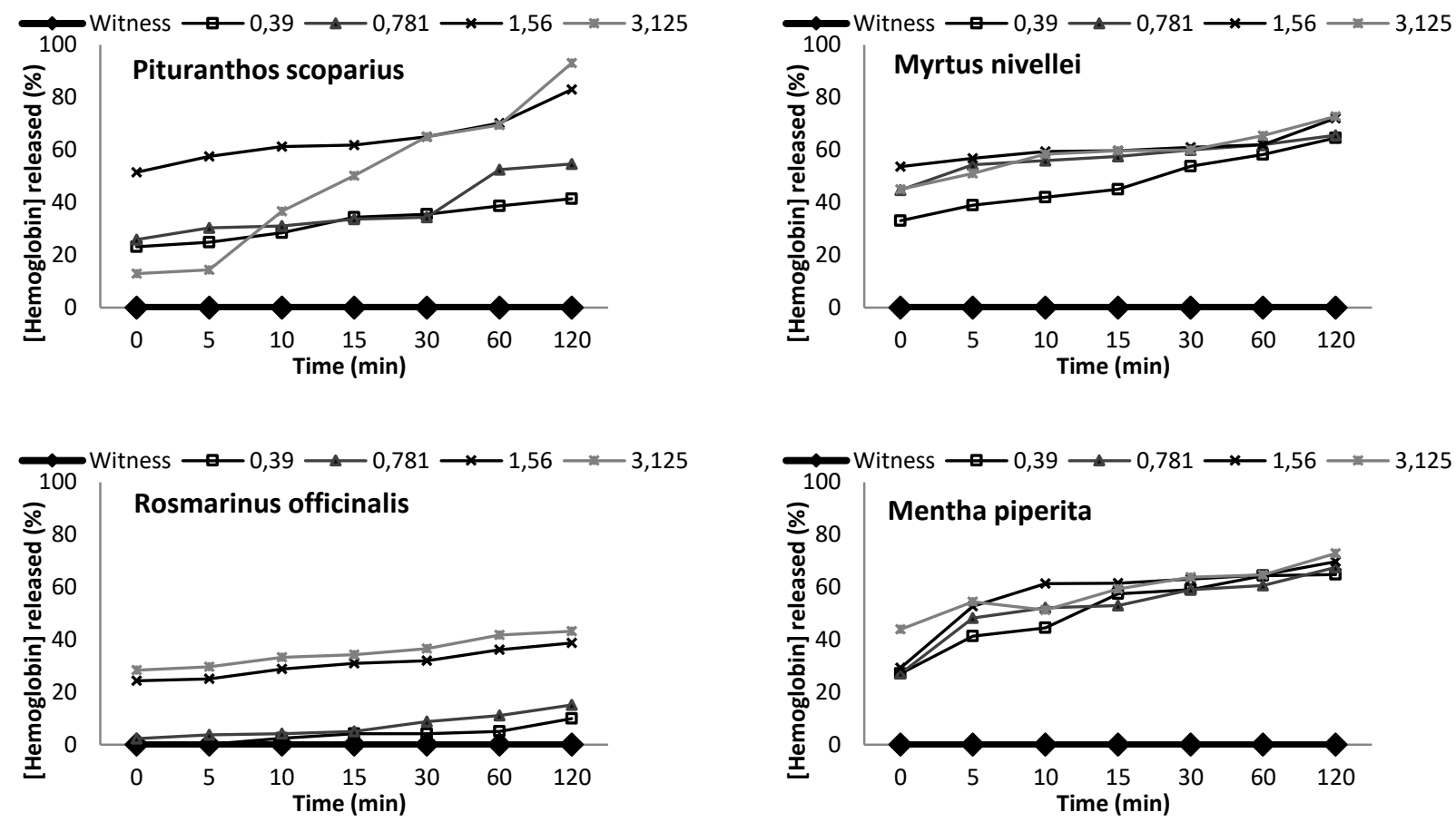

Figure 1. Release of hemoglobin by erythrocytes induced by different concentrations (mg/mL) of essential oils (Pituranthos scoparius, Myrtus nivellei, Rosmarinus officinalis and Mentha piperita).

Our results show that the essential oils of Rosmarinus officinalis have a very low toxic effect compared to isolated erythrocytes, with a haemolysis rate not exceeding $45 \%$ at a concentration of 3.1225 $\mathrm{mg} / \mathrm{mL}$, what characterizes it by the absence of risk of cytotoxicity. For other plants, they may be slightly hemolytic at high concentrations with respect to human erythrocytes.

Samber and his collaborators have shown that the rate of hemolysis of essential oil of Mentha pipireta against human red blood cells does not exceed $6 \%$ at a concentration of $2 \mathrm{mg} / \mathrm{mL}$ after one hour of incubation (Samber et al., 2015). Mendanha et al. (2013) report that terpenes can compete with the intermolecular hydrogen bond between lipid molecules and thereby disrupt the network of hydrogen bonds in the lipid bilayer, which weakens the membrane. As well, Jain et al. (2002) found that terpenes, which have alcoholic ' $\mathrm{OH}$ ' groups and which act as hydrogen bond donors, can disrupt the hydrogen bond network in the membrane bilayer.

According to some authors, the cytotoxicity of essential oils against red blood cells is due to their hydrophobic nature which is accentuated by the synergetic effect between their compounds (Sacchetti et al., 2005). Silva et al. (2017) suggest that the constituents present in oils can interact with the components of the erythrocyte membrane, leading to destabilization of its structure and to a disordered influx of ions and water which leads to rupture of the membranes.

\section{CONCLUSION}

The plants studied were harvested from areas of specific climate in Algeria. P. scoparius and M. piperita showed yields higher than $1 \%$. According to the antimicrobial activity results, all the strains showed sensitivity against the essential oils tested with the exception of the $C$. albicans against $R$. officinalis essential oils. The high content of polyphenols was reported in $P$. scoparius essential oils (14.78 $\pm 0.72 \mathrm{mg}$ GAE/g DS). The antioxidant test shows that the the essential oils of the four plants showed an antioxidant activity by scavenging of the free radical DPPH. Signally, the $R$. officinalis essential oils reported more antioxidant power than the positive control (ascorbic acid). The reducing power for all essential oils tested was by $\mathrm{EC}_{50}$ ranging from $9.67 \pm$ 
1.36 (R. officinalis) to $484.40 \pm 5.14 \mathrm{mg} / \mathrm{mL} \quad(P$. scoparius). Our results show that the essential oils of Rosmarinus officinalis had a very low toxic effect compared to isolated erythrocytes $(45 \%$ at 3.1225 $\mathrm{mg} / \mathrm{mL}$ ). From the results obtained, the geographical origin and period of harvest can influence the yield and the antioxidant activity of the essential oils of the studied plants.

Conflict of interest: The author declares that there are no conflicts of interest concerning the publication of this article.

\section{REFERENCES}

Abderrazak K, Messoued R, Azzedine Z (2013). Etude Phytochimique et de L'activité Antimicrobienne des Huiles Essentielles de Pituranthos Scoparius de la Region de Biskra (Sud-Est Algérien). Tunisian Journal of Medicinal Plants and Natural Products 10(2): xx-xx.

Akhtar N, Ihsan-ul-Haq Mirza B (2018). Phytochemical analysis and comprehensive evaluation of antimicrobial and antioxidant properties of 61 medicinal plant species. Arabian journal of chemistry 11 (8): 1223-1235.

APS (Algeria Press Service) (2019). Environnement: l'Observatoire national de la biodiversité inscrit dans la loi de Finances 2020 (La ministre de l'Environnement et des Energies renouvelables, Fatima Zohra Zerouati). Algeria Press Service. http://www.aps.dz/economie/89734environnement-l-observatoire-national-de-la-biodiversiteinscrit-dans-la-lf-2020.

Atanassova M, Georgieva S, Ivancheva K (2011). Total phenolic and total flavonoid contents, antioxidant capacity and biological contaminants in medicinal herbs. Journal of the University of Chemical Technology \& Metallurgy 46(1): 8188.

Bolard J (1986). How do the polyene macrolide antibiotics affect the cellular membrane properties?. Biochimica et Biophysica Acta (BBA)-Reviews on Biomembranes 864(3-4): 258-303.

Boukhalfa D (2017). Contribution à l'étude des plantes aromatiques et médicinales de la région de l'Ahaggar (Doctoral dissertation, University of Algiers, Algeria). http://193.194.83.98/jspui/bitstream/1635/14379/1/BOUKHA LFA_DJAMEL.pdf

Boutaghane N, Nacer A, Kabouche Z, Ait-Kaki B (2004). Comparative antibacterial activities of the essential oils of stems and seeds of Pituranthos scoparius from Algerian septentrional Sahara. Chemistry of natural compounds 40(6): 606-607.

Bouzabata A, Bazzali O, Cabral C, Gonçalves MJ, Cruz MT, Bighelli A, Cavaleiro C, Casanova J, Salgueiro L, Tomi F (2013). New compounds, chemical composition, antifungal activity and cytotoxicity of the essential oil from Myrtus nivellei Batt. \& Trab., an endemic species of Central Sahara. Journal of ethnopharmacology 149(3): 613-620.

Celiktas OY, Kocabas EH, Bedir E, Sukan FV, Ozek T, Baser KHC (2007). Antimicrobial activities of methanol extracts and essential oils of Rosmarinus officinalis, depending on location and seasonal variations. Food Chemistry 100(2): 553559.
Chikhoune A, Damjan Pavleca J, Shashkov M, Berroua Z, Chebbi K, Bougherra H, Zeroual B, Aliane K, Gagaoua M, Boudjellal A, Vovk I, Krizman M (2017). Antioxidant effect induced by the essential oil of Pituranthos scoparius in a formulation of a whey spread emulsion. Journal of Food Processing and Preservation 41(5): 1-12.

CLSI (Clinical and Laboratory Standards Institute) (2012). Methods for dilution antimicrobial susceptibility tests for bacteria that grow aerobically; approved standard-9th ed. CLSI document M07-A9. USA: Clinical and Laboratory Standards Institute, Wayne, PA.

CLSI (Clinical and Laboratory Standards Institute) (2008). Reference Method for Broth Dilution Antifungal Susceptibility Testing of Yeasts, Approved Standard, 3rd ed. CLSI Document M27-A3. USA: Clinical and Laboratory Standards Institute, Wayne, PA.

Derwich E, Benziane Z, Taouil R, Senhaji O, Touzani M (2010). Aromatic plants of morocco: GC/MS analysis of the essential oils of leaves of Mentha piperita. Advances in Environmental Biology 4(1): 80-86.

Dewanto V, Wu X, Adom KK, Liu RH (2002). Thermal processing enhances the nutritional value of tomatoes by increasing total antioxidant activity. Journal of agricultural and food chemistry 50(10): 3010-3014.

Djeddi S, Bouchenah N, Settar I, Skaltsa HD (2007). Composition and antimicrobial activity of the essential oil of Rosmarinus officinalis from Algeria. Chemistry of Natural Compounds 43(4): 487-490.

El Asbahani A, Miladi K, Badri W, Sala M, Addi EA, Casabianca H, El Mousadik A, Hartmann D, Jilale A, Renaud FNR, Elaissari A (2015). Essential oils: from extraction to encapsulation. International journal of pharmaceutics $483(1-$ 2): 220-243.

Espinel-Ingroff A, Cantón E (2007). Antifungal Susceptibility Testing of Yeasts. In: Richard S, Lynn S-M, Avery CG (eds) Antimicrobial susceptibility testing protocols. Taylor \& Francis Group LLC, pp. 173-208.

Gavahian M, Farhoosh R, Farahnaky A, Javidnia K, Shahidi F (2015). Evaluation of antioxidant activities of Mentha piperita essential oils obtained by different extraction methods. Iranian Food Science and Technology Research Journal 11(6): 729737.

Gourine N, Merrad B, Yousfi M, Stocker P, Gaydou EM (2011). Chemical composition of the essential oil of Pituranthos scoparius. Natural product communications 6(8): 1151-1154.

Haddouchi F, Chaouche TM, Halla N (2016). Phytochemical screening, antioxidant activities and hemolytic power of four Saharan plants from Algeria. Phytothérapie, 1-9.

Halla N, Boucherit K, Boucherit-Otmani Z, Touati FZ, Rahmani N, Aid I (2019a). Ammodaucus leucotrichus and Citrullus colocynthis from Algerian Sahara: Ethnopharmacological application, phytochemical screening, polyphenols content and antioxidant activity of hydromethanolic extracts. Journal of King Saud University-Science 31(4): 541-548.

Halla N, Boucherit K, Zeragui B, Hellal D, Bentoumi A, Belouafi L, Chikhi I, Boucherit-Otmani Z. (2019b). Essential Oil of Artemisia judaica L. (ssp. Sahariensis) from Algerian Sahara: Antimicrobial Effects and Mechanisms of Action. Phytothérapie. DOI 10.3166/phyto-2019-0187.

Hammiche V, Maiza K (2006). Traditional medicine in Central Sahara: pharmacopoeia of Tassili N'ajjer. Journal of ethnopharmacology 105(3): 358-367. 
İşcan G, Kïrïmer N, Kürkcüoğlu M, Başer HC, Demirci F (2002). Antimicrobial screening of Mentha piperita essential oils. Journal of agricultural and food chemistry 50(14): 3943-3946.

Jain AK, Thomas NS, Panchagnula R (2002). Transdermal drug delivery of imipramine hydrochloride.: I. Effect of terpenes. Journal of Controlled Release 79(1-3): 93-101.

Jordán MJ, Lax V, Rota MC, Lorán S, Sotomayor JA (2013). Effect of bioclimatic area on the essential oil composition and antibacterial activity of Rosmarinus officinalis L. Food Control 30(2): 463-468.

Kabouche Z, Boutaghane N, Laggoune S, Kabouche A, Ait-Kaki Z, Benlabed K (2005). Comparative antibacterial activity of five Lamiaceae essential oils from Algeria. International Journal of Aromatherapy 15(3):129-133.

Kalla A, Belkacemi D, Gherraf N, Zellagui A, Messai L, Ladjel S, Samir H, Brahim L, Chihi S (2010). Seasonal variability of essential oil content of Pituranthos scoparius. Asian Journal of Chemistry 22(4): 3065-3068.

Khaldi A (2014). La gestion non-durable de la steppe algérienne. VertigO-la revue électronique en sciences de l'environnement. https://doi.org/10.4000/vertigo.15152.

Ksouri A, Dob T, Belkebir A, Dahmane D, Nouasri A (2017). Volatile compounds and biological activities of aerial parts of Pituranthos scoparius (Coss and Dur) Schinz (Apiaceae) from Hoggar, southern Algeria. Tropical Journal of Pharmaceutical Research 16(1): 51-58.

Laghouiter OK, Gherib A, Laghouiter H (2015). Etude de l'activité antioxydante des huiles essentielles de certaines menthes cultivées dans la région de Ghardaïa. Revue ElWahat pour les Recherches et les Etudes 8(1): 84-93.

Lee YL, Ding P (2016). Production of essential oil in plants: ontogeny, secretory structures and seasonal variations. Pertanika Journal of Scholarly Research Reviews 2(1):1-10.

Lograda T, Ramdani M, Kiram A, Chalard P, Figueredo G (2013). Variation of essential oils composition of Pituranthos scoparius in Algeria. Global Journal of Research on Medicinal Plants \& Indigenous Medicine 2(1): 1-11.

Maffei M, Canova D, Bertea CM, Scannerini S (1999). UV-A effects on photomorphogenesis and essential-oil composition in Mentha piperita. Journal of Photochemistry and Photobiology B: Biology 52(1-3): 105-110.

Mahboubi M, Kazempour N (2014). Chemical composition and antimicrobial activity of peppermint (Mentha piperita L.) Essential oil. Songklanakarin Journal of Science and Technology 36(1): 83-87.

Mendanha SA, Moura SS, Anjos JL, Valadares MC, Alonso A (2013). Toxicity of terpenes on fibroblast cells compared to their hemolytic potential and increase in erythrocyte membrane fluidity. Toxicology in Vitro 27(1): 323-329.

Mohammadi A, Hashemi M, Hosseini M (2016). Antimicrobial Activity of Essential Oils of Cinnamomum zeylanicum, Mentha piperita, Zataria multiflora Boiss and Thymus vulgaris Against Pathogenic Bacteria. Medical Laboratory Journal 10(2): 32-40.

Halla N, Boucherit K, Boucherit-Otmani Z, Rahmoun N (2013). Erythrocyte toxicities of imidazolidinyl urea and diazolidinyl urea. Journal of Materials Science and Engineering. B 3(7B): 445 .

Oyaizu M (1986). Studies on products of the browning reaction - Antioxidative Activities of Products of Browning Reaction prepared from glucosamine. The Japanese journal of nutrition and dietetics, 44(6): 307-315.
Pereira PC, Cebola MJ, Bernardo-Gil MG (2009). Evolution of the yields and composition of essential oil from Portuguese myrtle (Myrtus comunis L.) through the vegetative cycle. Molecules 14(8): 3094-3105.

Prieto P, Pineda M, Aguilar M (1999). Spectrophotometric quantitation of antioxidant capacity through the formation of a phosphomolybdenum complex: specific application to the determination of vitamin E. Analytical Biochemistry 269(2):337-41.

Qaiyumi S (2007). Macro- and Microdilution Methods of Antimicrobial Susceptibility Testing. In: Richard S, Lynn SM, Avery CG (eds) Antimicrobial susceptibility testing protocols. Taylor \& Francis Group LLC, pp. 75-80.

Rached W, Benamar H, Bennaceur M, Marouf A (2010). Screening of the antioxidant potential of some Algerian indigenous plants. Journal of Biological Sciences 10(4): 316324.

Ramdane F, Essid R, Fares N, El Ouassis D, Aziz S, Mahammed MH, Didi Ould Hadj M, Limam F (2017). Antioxidant antileishmanial cytotoxic and antimicrobial activities of a local plant Myrtus nivellei from Algeria Sahara. Asian Pacific Journal of Tropical Biomedicine 7(8): 702-707.

Riachi LG, De Maria CA (2015). Peppermint antioxidants revisited. Food chemistry 176: 72-81.

Rohloff J, Dragland S, Mordal R, Iversen TH (2005). Effect of harvest time and drying method on biomass production, essential oil yield, and quality of peppermint (Menthax piperita L.). Journal of agricultural and food chemistry 53(10): 4143-4148.

Sacchetti G, Maietti S, Muzzoli M, Scaglianti M, Manfredini S, Radice M, Bruni R (2005). Comparative evaluation of 11 essential oils of different origin as functional antioxidants, antiradicals and antimicrobials in foods. Food chemistry 91(4): 621-632.

Saharkhiz MJ, Motamedi M, Zomorodian K, Pakshir K, Miri R, Hemyari K (2012). Chemical composition, antifungal and antibiofilm activities of the essential oil of Mentha piperita $\mathrm{L}$. ISRN pharmaceutics $2012: 1-6$.

Samber N, Khan A, Varma A, Manzoor N (2015). Synergistic anti-candidal activity and mode of action of Mentha piperita essential oil and its major components. Pharmaceutical biology 53(10): 1496-1504.

Sangwan NS, Farooqi AHA, Shabih F, Sangwan RS (2001). Regulation of essential oil production in plants. Plant growth regulation 34(1): 3-21.

Seca AM, Pinto DC (2019). Biological Potential and Medical Use of Secondary Metabolites. Medicines 6(2): 66.

Sharafi SM, Rasooli I, Owlia P, Taghizadeh M, Astaneh SDA (2010). Protective effects of bioactive phytochemicals from Mentha piperita with multiple health potentials. Pharmacognosy magazine 6(23): 147-153.

Silva LF, das Graças Cardoso M, Preté PSC, Teixeira ML, Nelson DL, Magalhães ML, Ferreira VRF, Souza RV, Soares LI, Marcussi S (2017). Essential Oils from Mentha viridis (L). L. and Mentha pulegium L.: Cytogenotoxic Effects on Human Cells. American Journal of Plant Sciences 8(6): 1423-1437.

Singh R, Shushni MA, Belkheir A (2015). Antibacterial and antioxidant activities of Mentha piperita L. Arabian Journal of Chemistry 8(3): 322-328.

Touaibia M, Chaouch FZ (2014). Evaluation of the antioxidant activity of aqueous, methanolic and ethanolic extracts of the Sahara-endemic species Myrtus nivellei Batt and Trab. 
(Myrtaceae). International Journal of Innovation and Applied Studies 6: 407-413.

Tyagi AK, Malik A (2011). Antimicrobial potential and chemical composition of Mentha piperita oil in liquid and vapour phase against food spoiling microorganisms. Food Control 22(11): 1707-1714.

Vérité P, Nacer A, Kabouche Z, Seguin E (2004). Composition of seeds and stems essential oils of Pituranthos scoparius (Coss. \& Dur.) Schinz. Flavour and fragrance journal 19(6): 562564.

Wojdyło A, Oszmiański J, Czemerys R (2007). Antioxidant activity and phenolic compounds in 32 selected herbs. Food chemistry 105(3): 940-949.
Zaouali Y, Bouzaine T, Boussaid M (2010). Essential oils composition in two Rosmarinus officinalis L. varieties and incidence for antimicrobial and antioxidant activities. Food and Chemical Toxicology 48(11): 3144-3152.

Zeragui B, Hachem K, Halla N, Kahloula K (2019). Essential Oil from Artemisia judaica L. (ssp. sahariensis) Flowers as a Natural Cosmetic Preservative: Chemical Composition, and Antioxidant and Antibacterial Activities. Journal of Essential Oil Bearing Plants 22(3): 685-694.

Zheng W, Wang SY (2001). Antioxidant activity and phenolic compounds in selected herbs. Journal of Agricultural and Food chemistry 49(11): 5165-5170. 
THIS PAGE INTENTIONALLY LEFT BLANK 